\title{
Incidence of Entamoebiasis Among Children In Abu -Ghraib Area Baghdad
}

\author{
Athmar k. Abass Al -Azawi \\ Dept. of Parasitology-Collage of Vet. Med. - Baghdad University \\ Baghdad -Iraq
}

\begin{abstract}
Summary
A total number of 600 fecal samples were collected from patients attaining general AbuGhraib hospital during the period from $1^{\text {st }}$ march 2006 till $28^{\text {th }}$ February 2007 . The samples were examined for detection of intestinal protozoan Entamoeba(E).histolytica infection by direct smear with Iodine stain and flotation technic using Zinc sulphat solution. The overall rate of infection was $32.5 \%$.Asignificant differences were observed in the rates of infection between males and females which constituted $46.44 \%, 25.64 \%$ respectively. All age groups were infected, the highest rate of infection $61.9 \%, 29.6 \%$ were noticed in males and females of 2-5 years old respectively, whereas the lowest rates $15.15 \%, 10 \%$ were recorded at the age of $9-11$ years respectively. The incidence of $E$. histolytica infection was observed allover the year, and the highest rates of infection $51.3 \%$, 38\% were recorded in spring and summer respectively .while the lowest rate $18.6 \%$ was noticed in full .Meanwhile it was $14 \%$ in winter season.
\end{abstract}

\section{انتشار داء الزحار الاميبي في الاطفال في منطقة ابو غريبـ بغداد}

$$
\begin{aligned}
& \text { أثنمار خضبر عباس العزاوي }
\end{aligned}
$$

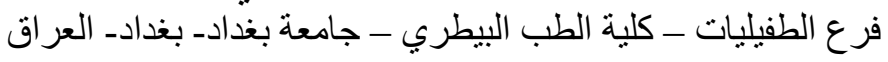

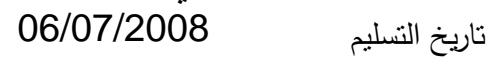

$$
\begin{aligned}
& \text { تاريخ القبول 111/11/2008 }
\end{aligned}
$$

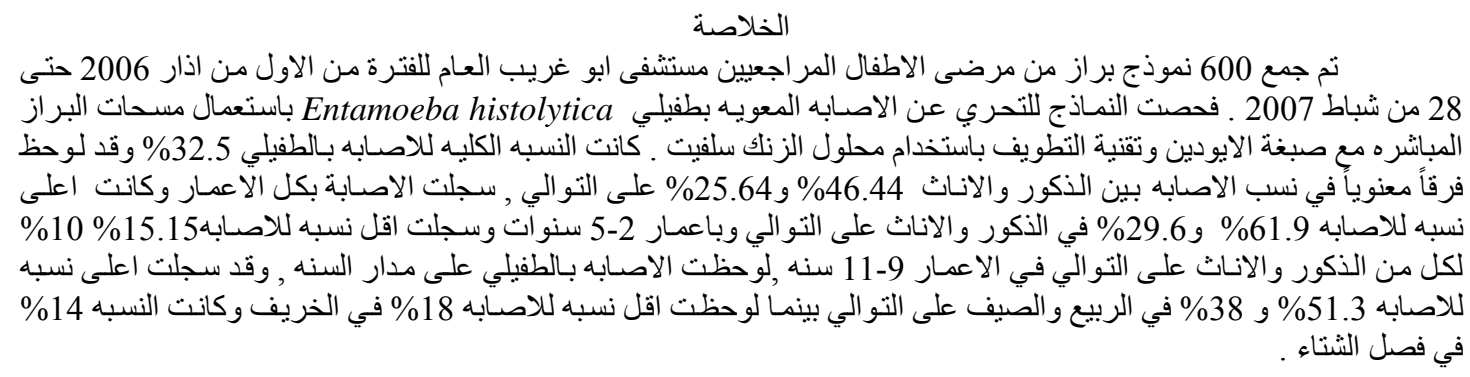

\section{Introduction}

Entamoeba[E] histolytica is well recognized as a pathogenic amoeba. The clinical features was a wide spectrum from asymptomatic luminal amoebiasis to invasive intestinal causing colitis and dysentery with extensive ulceration of the colon leading to sever bloody diarrhea which can be fatal due to perforation and peritonitis .The Infection may metastasizes to hepatic and pulmonary organs causing abscesses $(1,2)$.

Entamoebiasis is usually endemic and world wide with higher incidence in developing countries acquired by ingestion of viable cyst in contaminated food or water the infection is more prevalent and produce sever symptoms in warm climate, but in cooler climate in mental hospital, prison and children home with poor personal hygiene, were person to person contact is the methods of transmission ,the incidence is higher in compared with that of the general population of the same localities(2). In rural population in atemperate climate and throughout many tropical communities, transmission of infection upon negligence in personal hygiene and from food handlers and unpotable water supplied(3).The study is to assess the status of the infection and estimate the prevalence and seasonal variation in local 
area Abu Ghraib. Further is to fined out the effect of age, sex on the infection rate during one year period.

\section{Materials and Methods}

The study was conducted on 600 stool specimen [50 sample/month]were collected from children at age between 2-11 years old, during the period from $1^{\text {st }}$ march 2006 till $28^{\text {th }}$ February 2007. Children attaining Abu-Gharib hospital suffering from diarrhea, colic, abdominal pain in addition to lost appetite and loss of weight. Specimen submitted to the laboratory in clean container which labeled with name sex and date of collection. Examinations of stools were accomplished by direct smear preparation with iodine stained and flotation technique using zinc sulphate solution for detection and identification of parasite cyst, as described by (4). Examinations of smears were made under low power 10X then high power magnification.40X.

\section{Results}

The study revealed that the overall rate of infection with E.histolytica was $32.5 \%$ [table 1] .A significant difference were observed in the infection rates between males and females, the highest rate of infection was $170(46.66 \%)$ out of 366 males. While the lowest rate $60(25.64 \%)$ out of 234 was found in females [table 2]. According to the age groups the study showed that all age groups were susceptible to the infection with E.histolytica , the highest rate $61.9 \%, 29.6 \%$ were observed in males and females respectively at the age of $2-5$ years old, whereas the lowest rates $15.15 \%, 10 \%$ was recorded at the age group of 9-11 years for both males and females respectively ( table 3). In regarded to seasonal distribution the infection with E.histolytica was recorded all over the year ,the maximum rate 51.3\%.,38\% were found in Spring months ( March and April, May) and in Summer season (June , July , August, September) respectively the infection rate then declined and reached the minimum $18.6 \%$ in Autumn ( October, November, December). Then 14\% in winter season (January and February) [figure 1]. 
Table (1): Infection rates of E. histolytica during Months of the year

\begin{tabular}{|l|c|c|c|}
\hline Months & Sample(no) & Infected(no) & $\%$ \\
\hline March & 50 & 30 & 60 \\
\hline April & 50 & 25 & 50 \\
\hline May & 50 & 22 & 44 \\
\hline June & 50 & 22 & 44 \\
\hline July & 50 & 18 & 36 \\
\hline August & 50 & 18 & 36 \\
\hline September & 50 & 18 & 36 \\
\hline October & 50 & 10 & 20 \\
\hline November & 50 & 9 & 18 \\
\hline December & 50 & 9 & 18 \\
\hline January & 50 & 7 & 14 \\
\hline February & 50 & 7 & 14 \\
\hline Total & 600 & 195 & 32.5 \\
\hline
\end{tabular}

Table(2) : Rates of infection of E. histolytica (cyct) according to sexes.

\begin{tabular}{|c|c|c|c|c|c|c|}
\hline $\begin{array}{c}\text { Total } \\
\text { samples }\end{array}$ & $\begin{array}{c}\text { Males } \\
\text { (No) }\end{array}$ & $\begin{array}{c}\text { Infected } \\
\text { (No.) }\end{array}$ & $\%$ & Females(no) & $\begin{array}{c}\text { Infected } \\
\text { (No.) }\end{array}$ & $\%$ \\
\hline 600 & 366 & 170 & 46.44 & 234 & 60 & 25.64 \\
\hline
\end{tabular}

Table(3): Infected Rates In Males and females According To Age Groups

\begin{tabular}{|c|c|c|c|c|c|c|}
\hline $\begin{array}{c}\text { Age } \\
\text { groups }\end{array}$ & males(no) & Infected(no) & $\%$ & Females(no) & Infected(no) & $\%$ \\
\hline $2-5$ & 210 & 130 & 61.9 & 159 & 47 & 29.6 \\
\hline $6-8$ & 90 & 30 & 33.33 & 45 & 10 & 22.22 \\
\hline $9-11$ & 66 & 10 & 15.15 & 30 & 3 & 10 \\
\hline Total & 366 & 170 & 36.8 & 234 & 60 & 20.6 \\
\hline
\end{tabular}




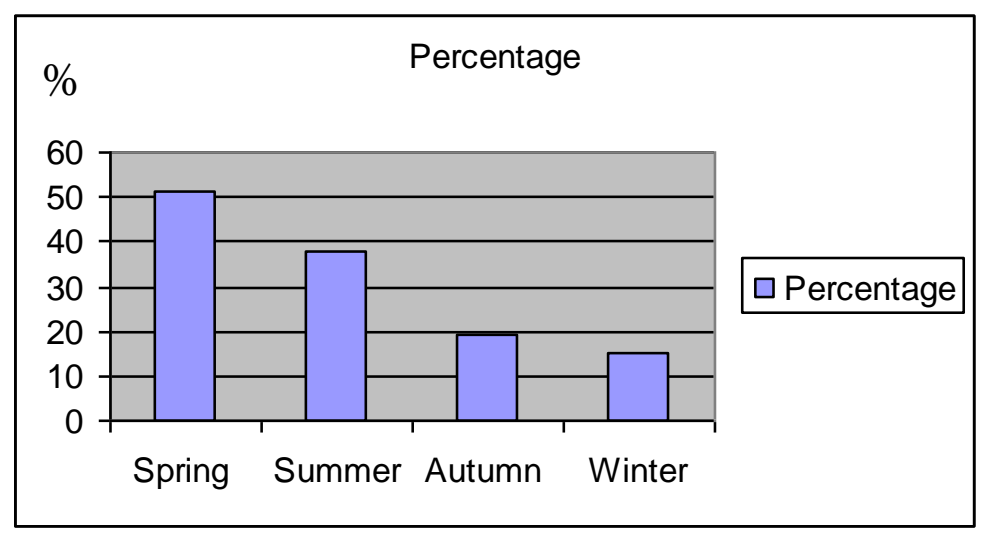

\section{Figure(1) : Infection rates with $E$. histolytica during seasons of year}

\section{Discussion}

Results revealed that the overall rate of infection with E.histolytica was $32.5 \%$, and when compared with the results of previous studies performed in Iraq, it was higher than the rate $23.8 \%$ which recorded by Rahif and Al-Saadi(5) in Baghdad city, and was in correspondence with (6) which recorded $31 \%$ and (7) result $35.6 \%$ in Al-Rammadi city . (8) found $10 \%$ pollution rate with parasite in tap water using from regions around Baghdad city. The higher incidence of infection in the present study was attributed to the area where the study applied, Abu_Ghraib area around Baghdad city which is suffered from a simple requirement of hygiene measurement especially at the last years, in this area combined sewer overflows and discharge raw sewage from sewer pipes into water ways are common contributors to high fecal pollution levels in Rural areas, infection also could be from food handlers . Result was in the line with observation of (9), (10). The higher incidence of the parasite were in rural areas compare to Urban communities, and the increase in the prevalence of infection in the world is due to pollution of drinking water with sewage .Result also compared with that recorded in many countries , in Jeddah -Sudai Arabia (11) recorded a rate 22\% , ( 12 ) found out $12 \%$ while (10) recorded $4 \%$, these rates were generally lower than had been reported in the present study, the lower prevalence and the disparities in the rates of infection where either upon improvement at the living standard in these countries or differences in the number of samples, age of the patient, the environment around the children or to the method used for detection parasite .Regarding the sex results had show the highest rate of infection $46.44 \%$ in males, while the lowest rate $25.64 \%$ was noticed in female children. These finding were in agreement with (7) and disagreement with (13) results which found a higher incidence in females rather than males due to nature of the society. Roberts (14) found that liver abscess due to ameobiasis in males were 7-10 times than females. (15) and (6) mentioned that there is no significant difference between males and females infection upon existing both in the same environment. We thought rural males exist frequently outside, playing with other children were person to person contact and contaminated food and water by which infection acquired make them more vulnerable to infection than females.

Results revealed that all age groups were infected and a higher incidence of infection $57.14 \%, 29.22 \%$ were observed among young children of 2-5 years old for both males and females whereas the infection rates were decline in males and females at age of 9-11 years, asimilar finding was recorded by $(16,17)$. (18) Noticed un increase in the infection rates reached 64.9\% in children down age school 1-3 years.

The fact that higher incidence of infection among young down 5 years old attributed to negligence in the cleaning, lack of appropriate hygiene measurement, low society level in families in rural areas or to the activity of children at this age and playing with other children and through contaminated food and water . ( 3 ) mention that person of all races, ages and both sixes appear to be equally susceptible to infection and differences in distribution can be explained in the basic of differences in exposure . 
It was shown that Entamobiasis was appeared all over the year, and significant differences in various months were detected. The highest incidencerate $51.3 \%, 38 \%$ were observed during spring and summer season, these rates were decline reached 14\% in autumn and winter season.These observation were in agreement with those reported by $(5,7,19)$ increasing in the rates of infection during spring and beginning of summer attributed to warm climate which is preferable for cyst to remain viable ,also activities of people during these season make them more exposure to source of infection . (20)claimed that the infection accrue more in moistureseason reached the min and in raining season than cold and dry.

Abu-Ghraib area as well as many rural areas in Baghdad were suffered from lack of tap water especially in summers people used water pump in these areas that raised the pollution problems in addition to that un potable and river water was used for ice made used for human consuming in hot summer, also drainage the human sewer in to the river and poor filtration of purification station of Baghdad city also dircthis greater opportunity for exposures to infection

It was concluded that investigation about Entamoeba histolytica infection in localities areas may provide reliable estimation of incidence of infection in large communities.

\section{References}

1. Mbaye,P.S.;Koff,N.:Camara,P.;Burgel,P.R.;Hovette,P.and Klotz,F.( 1998 )P.leuro Pulmonary manifestation of amebiasis .Rev.Pneumal .Clin.54( 6 ):346-352

2. Ravdin,J.I[2000]. Entamoeba histolytica [Amebiasis]. .In;Mandell; Principles and practice of disease. $5^{\text {th }}$ Ed.Philadelph;2798-807

3. Faust,E.C;Beaver,D.C and Jung.R.C.[1975].Animal agents and vectors of human disease,4th ed., Lea and Febiger.Philadelphia: 479pp.

4. W.H.O( 1991 ) Basic labroatory methods in medical parasitology 5 ;165-167 Geneva .

5. Rahif,R.H and AL_saadi,M.A.Z,[2001].prevalence and seasonal Distribution of intestinal parasite in children in Baghdad .[Iraq]. vet.j.,11\{3];10pp .

6. Hadi,A,m[2005].Prevalence of intestinal parasite in children in Baghdad AlRusafa.M.Sc.Thesis.Vet.Med.Coll.Baghdad.Univ. : 91pp.

7. Al-Dulaimi.k.A.[2001\}.Epidemiological Study of Entamoeba histolytica Parasite in Ramadi City.Msc Thesis.Sci Bio.AL- Anbar.Univ. 73pp .

8. .Hadi k.M . and farag. A.A. ( 2005 ) Distribution of intestinal parasites in drinking water in some regions in Baghdad. Al- Qadeseaa. J . Vol.22, No. ( 1 ), P 10.

9. Al-Hamadani, F.G.N. ( 1993 ). Parasitic infection in rural areas around Baghdad city. M.Sc.Thesis, Coll.Med .

10. FernandezM.C.:Verghese.S.;Bhuvaneswari,R.:Elizabeth.S.J. :Mathew.T.; Anit Ha.A. and Chitra,A.K.[2002]. A comparative study of the intestinal parasites prevalent among children living in rural and urban setting in and around Chennai.J.Commun.Dis. 34[1]:p 35-39

11. El-SKReikh.S.M. and El-Assouli.S.M.[2001].Prevalence of Viral Bacterial and Parasitic Enter pathogens among young children with Acute diarrhea in Jeudah .,SaudiArabia .J. Health. Popul .Nutr. 19[1]:p25_30.

12. Park .S. K.;Kim,D.H.,Deung,Y.K.,Kim,H.J.:Yang,E.J.;Lim.S.J.,Ryang,Y.S .:Jin,D.and Lee., K. J. [2004]. Status of Korean intestinal parasite infection in children bat Dambang Cambodia the j. parasitol.42 [4]; p201_203.

13. . Xu-L;Jiaus-z;Yu-S.Huany -D;Yang-S;Zhao $-\mathrm{G}$ and $\mathrm{Yu}-\mathrm{D}(1995)$ Survey of the distribution of human parasites in China-infection with parasites species in Human population ChungKuo -Chi-Shery Piry-Tsa-Chih 13(1):1-7.

14. - Robert,S.M[2002].Amebiasis.Am.J.Hyg.35:244-252.

15. . Diaz,E.;Mondragon.J;Ramirez,e. and Berna,R.[2003].Epidemiology and control of intestinal Parasites with Nitazoxanide in children in Mexico .Am.J.Trop.Med.Hyg.68[4]:P 384_385.

16. . Jaffer , E.11.(1998) incidence of intestinal Parasites among primary school children between these regions in Al-Doorah area-Baghdad Al-Mustansirriyah.J.Sci.

17. Arif, S.M.Ibrahim, Z.A. and Abdel Majced, N-Z. (2001) Survey on the prevalence of intestinal parasites among orphan children in habit two state homes in Baghdad city ,Bull.Iraq .Nat-Hist Mus 9(3):23-28.

18. Schmid, G.D. and Roberts , L.S. (1989) Foundation of parasitology .4thed, times mirror mjass.Coll.Puble.st.Louis:750pp. 
19 .Ali- Shtayeh, M.S.; Hamdea.A.H.X.;Abu-Zeid. I and Faidy. Y.R. ( 1989 ) perevalence and seasonal fluctuation of intestinal parasite in the Nables area west bank of Jordan . Ann.Trop.M.parasitol : 83 ( 1): 67-72

20. Neouimine, N.I.( 1994 ) .Intestinal parasitic infection .W.H.O.E.M.R.Epidemiol.Bull .No. 24: 614 . 